\title{
Cross-Border Capacity Assessment in Dementia Care
}

Citation for published version (APA):

Jongen, W., Commers, M. J., Schols, J. M. G. A., Burazeri, G., \& Brand, H. (2017). Cross-Border Capacity Assessment in Dementia Care. Das Gesundheitswesen, 79(10), E70-E77. https://doi.org/10.1055/s-0042121601

Document status and date:

Published: 01/10/2017

DOI:

10.1055/s-0042-121601

Document Version:

Publisher's PDF, also known as Version of record

Document license:

Taverne

Please check the document version of this publication:

- A submitted manuscript is the version of the article upon submission and before peer-review. There can be important differences between the submitted version and the official published version of record.

People interested in the research are advised to contact the author for the final version of the publication, or visit the DOI to the publisher's website.

- The final author version and the galley proof are versions of the publication after peer review.

- The final published version features the final layout of the paper including the volume, issue and page numbers.

Link to publication

\footnotetext{
General rights rights.

- You may freely distribute the URL identifying the publication in the public portal. please follow below link for the End User Agreement:

www.umlib.nl/taverne-license

Take down policy

If you believe that this document breaches copyright please contact us at:

repository@maastrichtuniversity.nl

providing details and we will investigate your claim.
}

Copyright and moral rights for the publications made accessible in the public portal are retained by the authors and/or other copyright owners and it is a condition of accessing publications that users recognise and abide by the legal requirements associated with these

- Users may download and print one copy of any publication from the public portal for the purpose of private study or research.

- You may not further distribute the material or use it for any profit-making activity or commercial gain

If the publication is distributed under the terms of Article $25 \mathrm{fa}$ of the Dutch Copyright Act, indicated by the "Taverne" license above, 


\section{Cross-Border Capacity Assessment in Dementia Care}

\section{Grenzüberschreitende Kapazitåtsbewertung der Demenzversorgung}

Authors

Wesley Jongen ${ }^{1}$, Matthew J. Commers ${ }^{1}$, Jos M.G.A. Schols ${ }^{2}$, Genc Burazeri' ${ }^{1}$, Helmut Brand ${ }^{1}$

Affiliations

1 International Health, Maastricht University, Maastricht, Netherlands

2 Health Services Research, Maastricht University, Maastricht, Netherlands

Keywords

capacity assessment, cross-border cooperation, dementia care

\section{Schlüsselwörter}

Kapazitätsbewertung, grenzüberschreitende Zusammenarbeit, Demenzversorgung

\section{Bibliography}

DOI http://dx.doi.org/10.1055/s-0042-121601

Online-Publikation: 2017 | Gesundheitswesen 2017; 79: e70-e77

(c) Georg Thieme Verlag KG Stuttgart · New York

ISSN 0941-3790

\section{Korrespondenzadresse}

Wesley Jongen, MSc

International Health

Maastricht University

PO Box 616

$6200 \mathrm{MD}$, Maastricht

Netherlands

w.jongen@maastrichtuniversity.nl

\footnotetext{
ABSTRACT

Introduction Within the Euregio Meuse-Rhine, cross-border cooperation in the healthcare sector has taken place on different occasions and at different levels. However, it still proving to be difficult to have an overview of the existing structures and activities of Euregio in specific healthcare fields, such as for instance, dementia care. The aim of this study is to examine to what extent cooperation in the Dutch province of Limburg in the field of dementia care can be considered Euregionally oriented.

Methods In order to create more cross-border transparency within the Euregional dementia care field, we conducted a capacity assessment analysis. Capacity assessment is the first step in the further development of healthcare capacities by mapping current as well as desired capacities. Although we related the model as applied in this study explicitly to dementia care in the Euregio Meuse-Rhine, the model could be applicable in other cross-border settings and/or healthcare fields as well.

Results Despite the apparently well-functioning system of regional dementia care networks in the Dutch province of Limburg, none of the respondents declared to have structural contacts with similar organizations in the other (German and Belgian) parts of the Euregio. Moreover, many of our respondents argued that cross-border cooperation
}

in the field of dementia care could be interesting in various ways, but at the same time there is currently no direct necessity to actively pursue such cooperation.

Conclusion Despite the absence of structural cross-border cooperation initiatives in the field of dementia care in the Euregio Meuse-Rhine, some suggestions can be made for the formulation of a potential capacity development response on the basis of the results of the capacity assessment as conducted in this study (showing gaps between current and desired capacities). Even if it is subsequently decided not to formulate a concrete capacity development response (for example due to the lack of a mutual objective need amongst organizations to engage in cross-border cooperation), a capacity assessment offers at the least a reflection on an organization's own performance as well as providing transparency between organizations. The main opportunities for the formulation of a capacity development response on a Euregional level in the field of dementia care are related to knowledge development and the creation of partnerships.

\section{ZUSAMMENFASSUNG}

Einleitung Innerhalb der Euregio Maas-Rhein (bestehend aus der niederländischen und der belgischen Provinz Limburg, der belgischen Provinz Lüttich sowie der (Städte)Region Aachen) hat grenzüberschreitende Zusammenarbeit im Gesundheitssektor, aus verschiedenen Veranlassungen und auf unterschiedlichen Ebenen, stattgefunden. Jedoch ist es schwierig einen Überblick in der Euregio zu behalten über die bestehenden Strukturen und Aktivitäten zu speziellen Versorgungsbereichen wie z. B. der Demenzversorgung. Ziel dieser Studie ist es, das Ausmaß der euregionalen Orientierung für eine Zusammenarbeit in der Demenzversorgung in der niederländischen Provinz Limburg zu untersuchen. Methoden Um mehr grenzüberschreitende Transparenz im Bereich der euregionalen Demenzversorgung zu erzeugen, wurde eine Kapazitätsbewertung vorgenommen. Eine Kapazitätsbewertung ist der erste Schritt in der Weiterentwicklung von Gesundheitsversorgungskapazitäten durch die Abbildung von bestehenden und gewünschten Kapazitäten. Obwohl wir das Model dieser Studie auf Demenzversorgung in der Euregio anwenden, könnte das Model auch auf andere Grenzregionen und/oder Gesundheitsbereiche anpassbar sein.

Ergebnisse Trotz anscheinend gut funktionierender regionaler Netzwerke in der Demenzversorgung in der niederländischen Provinz Limburg, erklärte keiner der Befragten, strukturelle Kontakte zu vergleichbaren Einrichtungen in anderen Teilen (Deutschland und Belgien) der Euregio zu haben. Darüber hinaus führten viele der Befragten an, dass eine grenzüberschreitende Zusammenarbeit im Bereich der Demenzversorgung auf verschiedene Weisen von Interesse sein könnte, gleichzeitig aber besteht derzeit keine direkte Notwendigkeit, eine solche Kooperation anzustreben. Schlussfolgerung Trotz des Ausbleibens von strukturellen grenzüberschreitenden Kooperationsinitiativen im Bereich der Demenzversorgung in der Euregio Maas-Rhein, können einige Formulierungsvorschläge für eine potenzielle Entwicklungsarbeit von Kapazitäten gemacht werden-basierend auf den Ergebnissen der Kapazitätsbewertung aus 
der vorliegenden Studie (mit Unterschieden zwischen derzeitigen und gewünschten Kapazitäten). Selbst wenn im Weiteren entschieden wird, eine konkrete Entwicklungsarbeit für Kapazitäten nicht zu formulieren (z. B. aufgrund einer nicht vorhandenen objektiven Notwendigkeit bei den Einrichtungen eine grenzüberschreitenden Kooperation zu beginnen), bietet eine Kapazitätsbewertung zumindest eine Reflexion über die eigene Leistungsfähigkeit einer Einrich- tung und schafft Transparenz zwischen den Einrichtungen. Die hauptsächlichen Chancen für die Formulierung von Entwicklungsarbeit von Kapazitäten auf euregionalem Niveau im Bereich der Demenzversorgung sind verbunden mit einer Wissensentwicklung und der Initiierung von Partnerschaften.

\section{Introduction}

On January 1, 2015, the Netherlands have witnessed a major reform of its long-term care system, characterized by (amongst others) a decentralization of long-term care responsibilities from the national government to the municipalities, accompanied by severe budget cuts in the long-term care sector. With regard to long-term care, the province of Limburg (particularly the southern part) has an interesting position within the Netherlands due to its above average aging pattern and its above-average percentage of inhabitants with one or more chronic diseases [1], even if adjusted for age and gender [2]. Moreover, due to its unique geographical location, in the proximity of both Germany and Belgium, Limburg can be considered within the Netherlands as an interesting testing ground for cross-border cooperation initiatives. Limburg is situated in the heart of the Euregio Meuse-Rhine (EMR), a cross-border cooperation arrangement between regional governments. The EMR contains 3,9 million inhabitants and comprises apart from the Dutch province of Limburg also the Belgian province of Limburg, the Belgian province of Liege, the German-speaking Community of Belgium and the Aachen region. In fact, cross-border cooperation has been given shape in many European internal border areas by the creation of such Euregios. Within the healthcare sector, Directive 2011/24/EU on 'patients' rights to cross-border health' even stimulates Member States to 'facilitate cooperation in cross-border healthcare provision at regional and local level' (Art. 10). Indeed, various good examples of such cross-border cooperation exist [3]. At the same time, as argued by Glinos, Wismar \& Palm, cross-border cooperation in healthcare is no easy endeavor, as "health care actors are rooted in their respective health systems and follow domestic rules, priorities and incentives' [4]. Also within the EMR setting, cross-border cooperation in the healthcare sector has taken place at different occasions and on different levels. Within the healthcare sector, particularly worth mentioning is the euPrevent|EMR programme, a Euregional network in the field of cross-border health prevention. However, despite the existence of networks such as euPrevent |EMR it still proves to be difficult to keep an overview of the existing structures and activities within specific healthcare fields, for instance dementia care, which is a key priority policy theme of both the Dutch province of Limburg as of the EMR. Indeed, as the population ages, a large and increasing number of people are living with dementia worldwide [5]. Also in the EMR region, more and more organizations active in the healthcare sector are searching for cooperation partners across the border, as appears for example from the numerous euPrevent|EMR projects and programs. However, in practice it often proves to be difficult to identify the right cooperation partners, especially as capacities within the healthcare sector have developed incrementally, but in different ways, in the different EMR regions. Although no sin- gle definition for the concept of 'capacities' (within the healthcare sector) exists, the concept at least consists of several dimensions (on the individual, organizational and societal level), such as financial resources, supportive laws, policies, strategies and procedures, well-functioning organizations, and educated and skilled professionals, required to plan, implement and review (health) strategies [6]. Moreover, in each region of each country, capacity development of professionals and organizations is an ongoing process, in order to meet new political, societal, or demographic challenges.

Capacity development has been described as 'the process through which individuals, organizations and societies obtain, strengthen and maintain the capabilities to set and achieve their own development objectives over time' [7]. Within the healthcare sector, capacity development has been defined as '[a]n approach to the development of sustainable skills, organisational structures, resources and commitment to health improvement in health and other sectors, to prolong and multiply health gains many times over' [8]. As Aluttis et al. suggest, this definition indicates that capacity building 'is not aimed at directly improving the population's health status, but at ensuring that the conditions are in place to achieve health improvement and to ensure that this can be multiplied and sustained over time, independent of external events' [9]. A first step in the further development of healthcare capacities, then, is the process of capacity assessment, in order to map current as well as desired capacities. Such a capacity assessment provides the necessary insights required to formulate capacity development objectives. Or, as a process that 'serves to provide an input for formulating a capacity development response that addresses those capacities that could be strengthened and that optimises existing capacities that are already strong and well founded. It can also set the baseline for continuous monitoring and evaluation of progress against relevant indicators and help create a solid foundation for long-term planning, implementation and sustainable results' [6].

In the Netherlands, cooperation in the field of dementia care is structured into more than 80 well-functioning regional dementia care networks. These networks were initiated by the Dutch government in 2008 by the so-called Ketenzorg Dementie (integrated dementia care) policy, in an attempt to integrate the care and support for people with dementia-as well as the support for their informal caregivers-into a system of multidisciplinary regional dementia care partnerships. The Dutch province of Limburg contains 5 such regional networks. Little is, however, known about the cross-border, Euregional, activities of these regional networks and the organizations involved. Various capacity development instruments have been developed in various sectors and for various purposes. However, no such tool appears to be developed specifically for the healthcare sector in a cross-border setting, which creates the premise for exploring this field in the current study. 
This study specifically focuses on this first step of the capacity development process, whereby capacity assessment can be considered here as a useful method to provide for the necessary cross-border transparency within Euregional dementia care. In this study, we conducted a Euregionally oriented capacity assessment in dementia care in the Dutch province of Limburg. As such, this study intends to answer the following research question: To what extent can cooperation in Limburg in dementia care be considered Euregionally oriented? As a sub-question we considered if and how, based on our capacity assessment results, suggestions could be made for the formulation of a potential capacity development response.

\section{Methods}

The capacity assessment model as applied in this study is essentially based on elements of the Capacity Assessment Framework as developed by the United Nations Development Programme (UNDP) $[6,7]$. That framework is not static in nature, but offers sufficient elements as building blocks for the development of a tailor-made capacity assessment and, eventually, a capacity development approach. Not every organization will decide to opt for the latter option, because of various reasons (such as a lack of resources, a lack of priority etc.). However, even if it is decided not to formulate a concrete capacity development response, a capacity assessment offers at the least a reflection on an organization's own performance as well as it provides for transparency between organizations.

The UNDP model focuses on several so-called 'functional capacities' that 'are needed to create, manage and review policies, legislations, strategies and programmes across levels of capacity (enabling environment, organizational, individual) and across core issues (institutional arrangements, leadership, knowledge, accountability)' [6].

The 5 functional capacities as addressed in the UNDP Capacity Assessment Framework are summarized below [6]:

- Capacity to engage stakeholders

- Capacity to assess a situation and define a vision and mandate

- Capacity to formulate policies and strategies

- Capacity to budget, manage and implement

- Capacity to evaluate

For the 'capacity assessment part' of this study we focused on this functional capacities dimension of the UNDP model, which we considered cyclical in nature here, being in line with the idea that organizations' capacities in the field of (cross-border) cooperation initiatives can be divided into stages (ranging from the initiation of first contacts, to the development of concrete cooperation projects, to the formation of a stable partnership that is regularly evaluated).

For the 'capacity development part' of this study we applied the 'core domains for public health capacity' as defined by Aluttis et al., which in its turn are partly based on the 'capacity building framework' as developed by the New South Wales (NSW) Health Department [10]. Although the Aluttis model and the NSW Health model thus partly overlap, we took the Aluttis model as a starting point, as the Aluttis model is specifically focused on the healthcare sector, takes country specific contexts into account (for example political contexts, as well as the different nature of healthcare systems) and is more comprehensive than the NSW Health mode.

- Table 1 gives an overview of the way the seven core domains are defined in this study, being largely in line with the original definitions as suggested by Aluttis et al. [9].

In short, the 'functional capacities' dimension (as based on the UNDP model) gives an insight into the stage(s) at which change or improvement should or could occur (derived from the gap between current and desired capacities); the 'core domains for public health capacity' dimension (as based on the Aluttis model) suggests ways of achieving this change.

For this study, we applied a mixed-method research approach, consisting of two subsequent steps [11]. First, participants were asked to complete an online quantitative survey. The survey questions were directly derived from the original UNDP model (divided into five categories/subscales) as discussed above and translated into Dutch [7]. Although we related the model in this study explicitly to dementia care, the model could be applicable in other healthcare fields as well due to its general setup. In that way, dementia care could be considered a test-case for application of this model in a cross-border setting. The questions are cyclical in nature, following the 5 categories of functional capacities as described above, implying that a respondent only reaches a next category when the previous category has been answered positively. Prior to the actual study, 2 test-interviews were conducted with scientific representatives in the long-term care field in Limburg, in order to test our questionnaire. Participants were asked to answer each question on a 5-point Likert scale, ranging from 'completely unable' to 'completely able'. Moreover, respondents had the opportu-

- Table 1 Core domains for public health capacity (derived from Aluttis et al. [9] and processed into own table).

\begin{tabular}{|c|c|}
\hline Domain & Definition \\
\hline Organizational structure & The infrastructural ability of the system to contribute to goals of public health. \\
\hline Workforce & $\begin{array}{l}\text { Qualified human resources with sufficient skills and knowledge; this also includes the availability of training } \\
\text { options. }\end{array}$ \\
\hline Resources & The allocation and provision of human and financial resources necessary to carry out public health activities. \\
\hline Partnerships & Collaboration between organizations for effective public health practice. \\
\hline Knowledge development & $\begin{array}{l}\text { The knowledge base that provides information on the health of the population and that supports evidence-based } \\
\text { public health policy and interventions at all levels. }\end{array}$ \\
\hline Leadership and governance & $\begin{array}{l}\text { The ability and willingness of governments [or other relevant stakeholders] to improve public health by developing } \\
\text { and implementing effective public health policies and by expressing qualities in leaderships and strategic thinking. }\end{array}$ \\
\hline $\begin{array}{l}\text { Country specific context with } \\
\text { relevance for public health }\end{array}$ & $\begin{array}{l}\text { The political context and other characteristics of a country that may have an influence on public health policies and } \\
\text { capacity building efforts. }\end{array}$ \\
\hline
\end{tabular}


nity to select a 'cannot answer this question' option. Moreover, each question had to be answered twice: on the one hand considered from the own regional situation (assessment of (potential) involvement in dementia care networks within Limburg), and on the other hand considered from the broader Euregional situation (assessment of (potential) involvement in dementia care networks in the EMR). Although a lot was already known about the regional Limburg situation, including the regional situation in our quantitative survey allowed for assessing possible correlations between 'regional' and 'Euregional' scores. As a second step in our mixed-method approach, participants were asked for an in-depth, semi-structured, interview after completion of the online questionnaire. The underlying reasons for this qualitative part of the study were twofold: on the one hand it allowed us to discuss, in-depth, the main findings of the quantitative survey; on the other hand, it allowed us to confront respondents with an additional set of qualitative questions ( $\triangleright$ Table 2 ) that were not covered in the survey, but gradually turned out to be of much relevance.

In contrast to the 'functional capacities' dimension (specifically geared towards the capacity assessment part of our study), the 'core domains for public health capacity' dimension (specifically geared towards the capacity development part of our study) were not explicitly included in the survey and interview questions, but instead derived from the survey and interview results. According to the UNDP model, a potential capacity development response is ideally only defined when those organizations involved in a capacity assessment process discuss the results of the assessment with each other. Only based on these results it can be decided to set priorities (or not) for a potential capacity development response. Therefore, this study focuses on the capacity assessment process; only suggestions will be made for a potential capacity development response.

20 representatives of various types of organizations involved in dementia care in the Dutch province of Limburg were approached for participation in this study. First, the coordinators of the 5 sub-re- gional dementia care networks in the province of Limburg were approached. Subsequently, we applied a snowball sampling technique, by asking each of these 5 representatives to provide use with 3 more respondents in their respective region. To be able to guarantee confidentiality, each of our respondents was asked to sign an informed consent. Because of our mixed-method research approach, anonymity of our respondents can only be guaranteed toward the readers of this article by omitting persons' and organizations' names. Of the 20 participants in the quantitative part of the study, 15 agreed to cooperate on the subsequent qualitative part of the study.

\section{Analyses}

For the quantitative part of the study, limited statistical analyses were performed: mean values and their respective $95 \%$ confidence intervals were calculated for both the 'Limburg' as the 'Euregio' responses. Furthermore, Spearman's rho (a non-parametric version of Pearson's correlation coefficient) was used to assess the linear association between the overall summary score of 'Limburg' and 'Euregio' responses. SPSS (Statistical Package for Social Sciences, version 15.0) was used for the statistical analyses.

Conversely, the qualitative interview data were analyzed by applying the grounded theory approach of open, axial, and selective coding, implying the principle of inductive reasoning and a constant comparison method [12].

\section{Results}

The descriptive, quantitative, survey results of the 'Limburg' part of our study are shown in $>$ Table 3.14 respondents answered all questions with a numerical score, having an average score of 3.8 per question for the 5 categories combined. The missing answers were mainly due to respondents skipping one or more questions.

The descriptive, quantitative, survey results of the 'Euregional' part of our study are shown in $>$ Table 4 . Only 10 respondents answered all questions with a numerical score, having an average

- Table 2 Additional qualitative interview questions.

1. To what extent are you familiar with (the work of) organizations in the dementia care field in the other parts of the Euregio (Belgian province of Limburg, the Belgian province of Liege, the German-speaking Community of Belgium and the Aachen region)?

2. To what extent do you consider cross-border between your organization and organizations in the dementia care field in the other parts of the Euregio as potentially beneficial?

3. What do you consider as the main barriers in searching for/realizing more such cross-border cooperation (if desired)?

4. What do you consider as the main requirements for achieving more such cross-border cooperation (if desired)?

5. What are your expectations with regard to your organization's potential future realization or expansion of cross-border cooperation initiatives?

- Table 3 Descriptive statistics for the overall summary score and the summary scores of each category for the 'Limburg' responses.

\begin{tabular}{|l|l|l|l|l|l|l|}
\hline Parameter & $\mathbf{1}^{\text {st }}$ subscale & $\mathbf{2}^{\text {nd }}$ subscale & $\mathbf{3}^{\text {rd }}$ subscale & $\mathbf{4}^{\text {th }}$ subscale & $\mathbf{5}^{\text {th }}$ subscale & Overall scale \\
\hline Valid number & 17 & 18 & 15 & 18 & 18 & 14 \\
\hline Missing values & 3 & 2 & 5 & 2 & 2 & 6 \\
\hline Mean & 22.1 & 14.8 & 14.7 & 11.8 & 12.1 & 76.1 \\
\hline Median & 24.0 & 15.0 & 16.0 & 12.0 & 12.0 & 80.5 \\
\hline Standard deviation & 5.1 & 2.7 & 3.1 & 2.8 & 2.4 & 14.0 \\
\hline Minimum & 11.0 & 8.0 & 9.0 & 8.0 & 6.0 & 43.0 \\
\hline Maximum & 30.0 & 19.0 & 19.0 & 15.0 & 15.0 & 93.0 \\
\hline
\end{tabular}


- Table 4 Descriptive statistics for the overall summary score and the summary scores of each category for the 'Euregio' responses.

\begin{tabular}{|l|l|l|l|l|l|l|}
\hline Parameter & $\mathbf{1}^{\text {st }}$ subscale & $\mathbf{2}^{\text {nd }}$ subscale & $\mathbf{3}^{\text {rd }}$ subscale & $\mathbf{4}^{\text {th }}$ subscale & $\mathbf{5}^{\text {th }}$ subscale & Overall scale \\
\hline Valid number & 13 & 13 & 10 & 12 & 12 & 10 \\
\hline Missing values & 7 & 7 & 10 & 8 & 8 & 10 \\
\hline Mean & 13.3 & 8.5 & 9.3 & 8.0 & 7.8 & 48.8 \\
\hline Median & 12.0 & 8.0 & 8.0 & 8.0 & 7.5 & 52.0 \\
\hline Standard deviation & 5.5 & 3.4 & 3.9 & 3.4 & 3.5 & 19.4 \\
\hline Minimum & 6.0 & 4.0 & 4.0 & 3.0 & 3.0 & 20.0 \\
\hline Maximum & 22.0 & 14.0 & 14.0 & 13.0 & 13.0 & 74.0 \\
\hline
\end{tabular}

score of 2.4 per question for the 5 categories combined. The missing answers were mainly due to respondents choosing the 'cannot answer' option.

The results of the Spearman's rho test (assessing a possible correlation between the overall summary score of the regional and Euregional responses) show a moderate yet borderline statistically significant correlation (Spearman's rho $=0.664, \mathrm{P}=0.051$ ).

In the qualitative part of the study we found that despite the apparent well-functioning system of the regional dementia care networks within the Netherlands, the situation is completely different when considered from a broader, Euregional, perspective. As a first step of the qualitative part of the study we discussed in-depth respondents' answers to the quantitative survey questions. Concerning the 'capacity to engage stakeholders' in Euregional dementia care, each of the respondents declared to have no structural contacts with similar organizations in the other (German and Belgian) parts of the Euregio. This holds both for the regional dementia care networks, as for the individual organizations within these networks. Only in a few occasional cases some of the respondents had some contacts with similar organizations abroad, but only because of personal interests or pre-existing personal contacts abroad, and on an occasional basis. As one of the respondents reported "1: "I have once participated in a Euregional conference (about ethics I thought). And the fact that I live in Belgium and work in the Netherlands helps in being aware of what is happening in both countries". The main reasons for not having structural contacts abroad were either having no mandate to do so, or because of non-awareness ("never thought about it actually", "I can't say that I currently miss the Euregional cooperation", as two of the respondents put it), or because of non-interest and/or non-priority (most of the regional dementia care networks, for example, are struggling to either broaden their network in their own respective region, or to guarantee structural, long-term, cooperation).

As a result of the answers to the "capacity to engage stakeholders' category, there were no response options in the other categories due to the cyclical nature of the questions as explained above. Merely concerning the 'capacity to assess a situation and define a vision and mandate', some respondents declared to occasionally consider policy documents of similar organizations abroad. As one of the respondents put it: "Having a look at each other's' vision is one thing, but a shared vision is still one step too far. [During a symposium in Germany] we listened to each other's stories and

${ }^{1}$ All of the respondents' quotes are the authors' own translations from Dutch to English. entered into dialogues with each other, but to talk about a similar vision...". There have, however, been no cases reported of comparing policies with foreign partners or defining common policies. Moreover, those respondents that occasionally considered foreign policy documents did not limit this approach to the Euregio, but also considered policy documents of organizations in the rest of Europe or even the rest of the world.

In order to gain more insight into the above conclusions for the Euregional situation we confronted our respondents with an additional set of 5 qualitative questions ( $\triangleright$ Table 2 ). While the original questions were mainly based on capacity in terms of an actual situation (that appeared to be almost non-existing when considered from a Euregional perspective), the additional set of questions was much more based on a potentially desired situation. The first of these questions was focused on whether or not being familiar with (the work of) organizations in their field in the other parts of the Euregio. While most of the respondents reported to be unfamiliar with (the work of) such foreign organizations, some respondents reported to have some knowledge about this, which is in line with the results mentioned in the previous paragraph. Apart from knowledge acquired by reading reports or policy documents, knowledge was acquired by attending Euregional symposia focused on a particular theme, notably on 'dementia friendly communities' initiatives or on informal care - the latter being indeed a much more common phenomenon in Belgium and Germany than in the Netherlands [13]. Or, as one respondent put it: "I know about it [the work of similar organizations in the other parts of the Euregio], but I am also well aware of the fact that I don't know by far as much about those regions than about my own region or the surrounding regions [within the Netherlands]".

The next question was focused on respondents' views about the potential advantages of cooperating with similar organizations in the other parts of the Euregio. General conclusion was that primarily healthcare professionals and municipalities, instead of clients, could benefit from such cross border cooperation. Examples included the exchange of knowledge and best practices. As one of the respondents reported: "There might well be things happening in the Euregion of which we would say, gee, interesting, we never thought about thát. So I think we would never reject such information. If we would get information or possibilities we would make use of it, but it is currently not up to us". Some respondents argued that obtaining such knowledge requires exchange projects for employees of healthcare organizations and municipalities in order to experience the work culture in foreign organizations. Others argued that such knowledge can equally be obtained without actual con- 
tact across the border - for example by making use of comparative studies. Next, respondents pointed to the potential advantage of benchmarking one's own organization's or region's performance to that of other, foreign, organizations or regions, within the context of mutual learning. Again, there appears to be no direct added value of limiting such initiatives to the Euregional context. As one of the respondents argued: "It would be good to consider the functioning of the elderly care system elsewhere, on a national level, or on Euregional level, that doesn't matter so much". Our respondents believe that clients only benefit in an indirect way from such initiatives, as a result of a better quality of care they may eventually lead to. Potential advantages in terms of cross border patient mobility - as referred to in Directive 2011/24/EU - are much less obvious in the field of long-term care than for example in the field of medical care. In fact, long-term care is explicitly excluded from this Directive (Recital 14). A number of respondents, finally, reported to see no direct advantages of more cross-border cooperation in the field of dementia care, as the functioning of the regional dementia care networks in Limburg is in general highly valued by most of the participating organizations, whereby organizations already learn a lot from each other due to the multidisciplinary approach of the networks. As one respondent put it: "At the moment we are still busy enough with ourselves and we are satisfied with the connections and contacts we have and there are still sufficient opportunities to expand these. So we haven't yet had the need to have a look across the border (so really the national border)".

With regard to the third question, the main barriers in searching for more cross-border cooperation (if desired) lie according to our respondents in the fact that the differences in healthcare systems between the 3 countries often impede practical cooperation with organizations across the border. Or, as one respondent reported: "There are cultural differences. These are very concrete barriers". Moreover, many organizations have to deal with scarce resources (especially, as argued by Jongen et al. [14], after the entry into force of the Dutch long-term care reform), which means setting priorities; cross-border cooperation mostly is not such a priority. Or, as one respondent put it: "You know, there is currently so much going on within our own healthcare system, which costs me so much time and energy, that I wouldn't even want to think about it [Euregional cooperation]". Finally, as reported before, many of our respondents argued that cross-border cooperation could be interesting in various ways, but there is currently no direct necessity to actively pursue such cooperation in the field of dementia care.

With regard to the question on what is needed to achieve more cross-border cooperation (if desired), our respondents mainly pointed to the importance of a third party taking the lead in this. Such a third party should ideally be a neutral organization, with a broad view on the long-term care sector in different countries. This 'umbrella' organization should act as a 'driving force', being capable of not only connecting organizations, but also triggering organizations to actively participate. As one respondent put it: "I think the incentive [stimulation of cross-border knowledge sharing] must come from euPrevent, or similar organizations working Euregionally". Another respondent suggested a role for the regional government: "The Province [Dutch Province of Limburg] could play an important role. [...] The Province has a lot of Euregional contacts and I think they could do a lot of preparatory work. Being able to break new grounds. Eventually the work, depending on the goals set, will have to be done by, let's say, the 'specialist' organizations". Moreover, in order to come to a solid, long-term, cooperation model, searching for win-win situations (wherein the interests of all countries involved are met) is a prerequisite. Next, even though cross-border contacts may well be facilitated by a third party, concrete cross-border initiatives should eventually be developed in a bottom-up manner by organizations themselves. Finally, any system facilitating cross-border cooperation should be flexible in nature, as cooperation needs may often appear spontaneously as a result of recent, sometimes unforeseen, developments in the healthcare sector.

Concerning organizations' expectations with regard to their potential future realisation or expansion of cross-border cooperation initiatives (last question), our respondents reported not to expect any significant developments in the near future. However, respondents were prone to possible developments in the longer-term, under the aforementioned conditions. As one respondent summarized quite well: "We are still in a situation wherein we have limited resources and are dependent of budgets of health insurers. [...] However, we are involved in a regional dementia care network in order to improve the quality of care, together with other healthcare organizations. So if this [improvement of care quality] could be achieved with a Euregional approach I would be equally interested in that as well".

\section{Discussion}

In this final section, we discuss the principal findings of the current study (relating to our main research question) and move towards their broader implications (in terms of suggestions for the formulation of a potential capacity development response).

\section{Principal findings}

With regard to our first research question (Euregionally oriented capacity assessment in dementia care), it can be concluded that although well-functioning multidisciplinary regional dementia care networks exist within the Netherlands, no such structural cooperation appeared to exist in a cross-border Euregional setting. The absence of such cross-border cooperation initiatives is mainly due to the fact that there appeared to be no direct sense of urgency among respondents to develop such initiatives, and organizations are consequently unwilling to make capacity available for such purposes. At the same time, respondents appeared to be willing to consider participation in cross-border initiatives in cases of direct relevance. Cross-border cooperation, they argued, should not be an aim in itself, but is only of added value when there is a direct necessity to search for additional knowhow. An example of the latter is that a lot of organizations reported to be interested in experiences from other countries that have recently had a similar long-term care reform and/or decentralization situation as in the Netherlands, as this is a completely new situation Dutch organizations now have to deal with. This reform is, as argued by Jongen et al., 'characterized by major changes of its long-term care system taking place at a relatively rapid pace, starting in times of a severe economic crisis and entering into force in the wake of this crisis', and 'accompanied by severe budget cuts' [14]. The existence of barriers for co- 
operation in health and social service delivery across borders in largely publicly-subsidized services has become clear in this study. Substantial efforts to overcome these barriers will only be made if organizations are convinced of the added value to do so. This conclusion is in line with the findings of Glinos, Wismar \& Palm, indicating that several factors are needed to initiate and maintain crossborder cooperation, including 'an objective need as CBC [crossborder collaboration] must serve a concrete purpose'; 'committed individuals who invest time and effort in the cross-border cooperation project; shared interests among partners to ensure that all are working towards a common goal which cannot be obtained separately; external support from local stakeholders, public authorities and funding institutions; and a governance structure which suits the purposes, partners and health systems involved in the cross-border cooperation' [4].

With regard to the results of the Spearman's rho test we found a moderately positive correlation between the quantitative responses of the 'Limburg' scores and those of the 'Euregio' scores, implying that organizations which score high on regional cooperation also tend to score higher on Euregional cooperation than those organizations which score low on regional cooperation. This result (although on the border of statistical significance) is in line with our qualitative findings: those respondents that reported to have some knowledge about, or some contacts with, Euregional organizations were those respondents that were also actively engaged within the Dutch regional dementia care networks. In other words: cross-border cooperation also requires personal engagement of employees willing and motivated to be actively engaged in network collaboration. Moreover, the mean values indicated that respondents were more involved in regional cooperation than in Euregional cooperation, which is in line with our qualitative findings. With regard to these mean values, it has to be added that the Euregio scores were less normally distributed than the Limburg answers (or, in other words, more variance in answers in the Euregio scores than in the Limburg scores). Although also these results match with our qualitative findings, the mean values as such are of little statistical significance due to the low number of valid responses among the already low number of respondents.

\section{Broader implications}

With regard to our sub research question then (suggestions for the formulation of a potential capacity development response), indeed some suggestions can be made for the formulation of a potential capacity development response, based on the results of the Euregionally oriented capacity assessment as conducted in this study. Even if organizations do not decide to opt for the formulation of concrete capacity development objectives, these suggestions at the least provide the opportunity for a self-reflection on the functioning of individuals, organizations and societies, as well as transparency between individuals, organizations and societies about each other's functioning (e. g. for benchmarking or mutual learning aims). Important to emphasize here is that the suggestions that are made are based on an aggregated conclusion for approaching dementia as a societal problem or a societal challenge on the Euregional level. The conclusion (capacity development response) for individual organizations can and will differ from this aggregated conclusion, depending on the specific current and desired capaci- ties (and the gap between them) applying to that organization.

The main opportunities for the formulation of a capacity development response on a Euregional level in the field of dementia care, are - in terms of Aluttis et al.'s core domains for public health capacity - situated within the domains 'knowledge development', 'partnerships' and (primarily resulting from the former two domains) 'organisational structure' and 'leadership and governance'. 'Knowledge development' (primarily in terms of knowledge sharing) was considered by the majority of our respondents as the most obvious reason for potentially considering the work of similar organizations across the border. However, in order to come to a situation wherein knowledge sharing can be organized in a structural way, instead of on an ad-hoc basis, it is key to further develop already existing (or create new) suitable Euregional cooperation structures ('partnerships'). In order to stimulate organizations to create or further develop such partnerships, the existence of a genuinely shared interest is, in line with the findings of Glinos, Wismar \& Palm [4], indispensable. Moreover, also in line with the findings of Glinos, Wismar \& Palm [4], it requires a governance structure within each of the individual organizations involved, that suits the purposes of the respective cross-border cooperation initiative ('organisational structure'). Most of the individual organizations we interviewed, however, currently lack the existence of an objective need for cross-border cooperation, as well as the existence of a governance structure that is suitable for structural cross-border cooperation initiatives, mainly as a result of other, more prevalent, priorities. Much is therefore in this respect expected of those organizations that already somehow fulfill an overarching 'umbrella' role (such as the dementia care networks on a regional Limburg level). Regardless of which organization could and would like to fulfill this role, it is clear that the majority of respondents consider the intervention of a third party as facilitator as a precondition for their potential future involvement in cross-border cooperation projects or structures ('leadership and governance'). Preconditions for making progress within the aforementioned core domains, then, are the available financial and human resources an organizations has at its disposal ('resources' and 'workforce'). Both financial and human resources are currently scarce in many organization active in the long-term care sector, especially as a result of the budget cuts accompanying the current Dutch long-term care reform. Moreover, most of these organizations do not appear to have any budget available for cross-border cooperation initiatives, due to a lack of priority of such initiatives. However, even with limited resources, tangible results can be achieved within individual organizations. An example includes the appointment of a dedicated employee within an organization, who will be allowed to devote a limited amount of time on cross-border cooperation initiatives (minimally by maintaining cross-border contacts and sharing relevant information with these contacts). The resources for creating and maintaining a truly structural cross-border partnership are most likely to be found with external funders, such as local governments and/or private investors. Finally, there are some external factors that organizations are unlikely to influence, but that are nonetheless worth taking into account when formulating a potential capacity development response. Most noteworthy in the case of a potential Euregional approach in the field of dementia care is the mere fact that national healthcare systems differ. These differences often impede the cooperation across borders in a practical way, for example 
due to differences in policy priorities between governments or due to different funding channels for projects ('country specific context').

\section{Study limitations and suggestions for further research}

Although the principle strength of this study has been its structured and cyclical approach of assessing the capacities of organizations (thereby separating true structural networks from mere adhoc, coincident, contacts) in a yet unexplored setting (dementia care in a cross-border setting), its quantitative approach has probably been its largest weakness. Indeed, despite the positive testresults prior to the actual study, respondents declared the survey questions to be too abstract. At the same time, this quantitative flaw has been captured to a large extent - at least for answering our first research question - by the qualitative part of the study, as the latter allowed to discuss in-depth respondents' survey results and to extend the scope of the survey from mere current capacity assessment to the assessment of potentially desired capacities. Particularly in still undeveloped networks such as in the case of Euregional cooperation in dementia care, the latter may be worth considering, for example by triggering organizations by sharing best practice experiences or by giving advice on how to potentially develop capacity - possibly in predefined categories such as the core domains for public health capacity, as suggested by Aluttis et al. [9]. Another potential weakness of this study has been the fact that no capacity assessments have been performed in the other EMR regions and that it was focused merely on dementia care and no other healthcare fields. However, it is particularly this weakness that provides opportunities for further research, particularly as respondents themselves pointed to the potential added value of conducting capacity assessments related to other topics. Therefore, we suggest conducting capacity assessments (based on current as well as potentially desired capacities) in a number of neighboring countries (within the context of this study, notably the Netherlands, Germany and Belgium), thereby ideally encompassing a broader array of topics than merely dementia.

\section{Acknowledgements}

Wir möchten uns bei euPrevent|EMR und der niederländischen Provinz Limburg für die Hilfe bei der Durchführung dieser Studie bedanken. Weder euPrevent | EMR noch die Provinz Limburg haben Einfluss auf den Untersuchungsansatz, die Auswertung der Daten oder das Artikelmanuskript genommen. Letztlich möchten wir uns bei Timo Clemens, MSc (Abteilung 'International Health', Maastricht University) für die Übersetzung von Textteilen ins Deutsche bedanken.

\section{Conflict of interest}

The authors have no conflict of interest to disclose.

\section{References}

[1] National Institute of Public Health and the Environment (RIVM). Vergrijzing: Zijn er in Nederland verschillen naar regio? Internet: http://www.nationaalkompas.nl/bevolking/vergrijzing/zijn-er-innederland-verschillen-naar-regio/ Accessed: 18.01.2016

[2] National Institute of Public Health and the Environment (RIVM). Eén of meer chronische ziekten 2012. Internet: http://www.zorgatlas.nl/ gezondheid-en-ziekte/ziekten-en-aandoeningen/chronische-ziektenen-multimorbiditeit/een-of-meer-chronische-ziekten\#breadcrumb Accessed: 19.01.2016

[3] McKee M, Busse R, Baeten R et al. Cross-border health care collaboration in the European Union: Placing the patient at the centre. Eurohealth 2013; 19: 3-5

[4] Glinos IA, Wismar M, Palm W. Cross-border collaboration in health care: When does it work? Eur J Public Health 2014; 24: (Suppl 2)

[5] Livingston G, Frankish H. A global perspective on dementia care: A Lancet Commission. Lancet 2015; 386: 933-934

[6] UNDP. Capacity Assessment practice note. New York: United Nations Development Programme; 2008

[7] UNDP. Capacity Development practice note. New York: United Nations Development Programme; 2008

[8] Hawe P, Noort M, King L et al. Multiplying health gains: The critical role of capacity-building within public health programs. Health Policy 1997; 39: 29-42

[9] Aluttis C, Van den Broucke S, Chiotan C et al. Public health and health promotion capacity at national and regional level: A review of conceptual frameworks. J Public Health Res 2014; 3: 37-42

[10] NSW Health. A framework for building capacity to improve health. Sydney: NSW Health Department; 2001

[11] Creswell JW. Research design: Qualitative, quantitative, and mixed methods approaches. Los Angeles: Sage; 2009

[12] Glaser BG, Strauss AL. The Discovery of Grounded Research: Strategies for qualitative research. New York: Aldine De Gruyter; 1967

[13] Jongen W, Burazeri $G$, Brand $H$. The influence of the economic crisis on quality of care for older people: System readiness for innovation in Europe. CIEJ 2015; 28: 167-191

[14] Jongen W, Commers M], Schols JMGA et al. The dutch long-term care system in transition: Implications for municipalities. Gesundheitswesen 2016; 78: e53-e61 